\title{
Differences in fat metabolism between predicted survivors and non-survivors of faecal peritonitis
}

\author{
A Kleyman ${ }^{1 *}$, W Khaliq ${ }^{2}$, S Neugebauer ${ }^{1}$, M Gräler ${ }^{1}$, M Kiehntopf $^{1}$, M Singer $^{2}$ \\ From ESICM LIVES 2015 \\ Berlin, Germany. 3-7 October 2015
}

\section{Introduction}

A switch from carbohydrate to fat as a fuel source is a hallmark of systemic inflammation. This adaptive reaction allows animals to survive under restricted food supply conditions. However, a prolonged and excessive stimulation of lipid metabolism may be detrimental.

\section{Objectives}

Using our well-characterized $72 \mathrm{~h}$ fluid-resuscitated rat model of faecal peritonitis (1), where accurate prognostication can be made as early as $6 \mathrm{~h}$, we investigated differences in fat metabolism between predicted survivors (S) and non-survivors (NS).

\section{Methods}

Awake, instrumented yet fully mobile male Wistar rats $(325 \pm 15 \mathrm{~g})$ received an i.p. injection of $4 \mu \mathrm{l} / \mathrm{g}$ faecal slurry. Fluid resuscitation (50:50 mix of $5 \%$ glucose/ Hartmann's; $10 \mathrm{ml} / \mathrm{kg} / \mathrm{h}$ ) was commenced at $2 \mathrm{~h}$. At $6 \mathrm{~h}$, an echo-measured heart rate cut-off of $460 \mathrm{bpm}$ was used to classify animals into predicted S or NS. Control animals were treated identically except for slurry injection. Blood samples were taken for measurement of hormones and metabolites at 6 and 24h. Results were analysed using two-way ANOVA and post-hoc testing, and considered statistically significant when $\mathrm{p}<0.05$.

\section{Results}

At $6 \mathrm{~h}$ after sepsis initiation, concentrations of the lipolytic agents, adrenaline and brain natriuretic peptide, were significantly higher in NS (Table 1). The rise in plasma free fatty acids (FFA) was similar in both S and NS. Plasma glucagon and the glucagon:insulin ratio were higher while triglyceride and cholesterol concentrations were significantly lower in NS; this is perhaps explained by glucagon-induced repression of hepatic fatty acid and cholesterol synthesis (2). NS had higher plasma concentrations of ketone bodies and acetylcarnitine, suggesting

Table 1

\begin{tabular}{llll}
\hline & Control & Survival & Predicted Non-Survival \\
\hline Adrenaline & $8.56 \pm 0.42$ & $9.44 \pm 0.23$ & $10.3 \pm 0.18$ \\
\hline B-natriuretic peptide & $118 \pm 22$ & $196 \pm 35$ & $1318 \pm 320 \mathrm{a}$ \\
\hline Glucagon & $53 \pm 5$ & $62 \pm 4$ & $75 \pm 5 \mathrm{a}$ \\
\hline Insulin & $0.54 \pm 0.25$ & $0.86 \pm 0.22$ & $0.87 \pm 0.13$ \\
\hline Triglycerides & $1.22 \pm 0.08$ & $1.12 \pm 0.04$ & $0.75 \pm 0.08 \mathrm{a}, \mathrm{b}$ \\
\hline FFA mg/dL & $167 \pm 27$ & $514 \pm 109$ & $456 \pm 122 \mathrm{a}$ \\
\hline Acetoacetate $(\mathrm{AA}) \mu \mathrm{mol} / \mathrm{L}$ & $91 \pm 9$ & $78 \pm 57$ & $207 \pm 122$ \\
\hline 3-hydroxybutyrate $(3 \mathrm{HB}) \mu \mathrm{mol} / \mathrm{L}$ & $97 \pm 8$ & $259 \pm 49$ & $355 \pm 99 \mathrm{a}$ \\
\hline Acetylcarnitine $\mu \mathrm{M}$ & $9.73 \pm 0.40$ & $10.02 \pm 0.88$ & $16.75 \pm 3.25 \mathrm{a}, \mathrm{b}$
\end{tabular}

University Hospital Jena, Department of Anesthesiology and Intensive Care

Medicine, Jena, Germany

Full list of author information is available at the end of the article 
different utilization of acetylCoA groups between $\mathrm{S}$ and NS. The plasma acetoacetate/3-hydroxybutyrate ratio was similar in S and NS at $6 \mathrm{~h}$ but increased at $24 \mathrm{~h}$ in S and decreased in NS, reflecting alterations in redox potential and the hepatic $\mathrm{NAD}^{+}: \mathrm{NADH}$ ratio (3).

\section{Conclusions}

Predicted non-survivor rats demonstrated a greater stress response to sepsis accompanied by greater alterations in fat metabolism. The consequences of these changes in energy metabolism on the development of organ failure merit further investigation, as this may lead to novel directed therapeutics.

\section{Grant Acknowledgment}

ESICM Basic Science Award, Intensive Care Foundation (UK), NIHR.

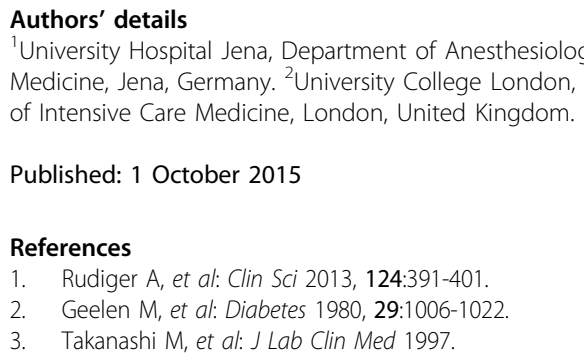

Published: 1 October 2015

\section{References}

1. Rudiger A, et al: Clin Sci 2013, 124:391-401.

2. Geelen M, et al: Diabetes 1980, 29:1006-1022

3. Takanashi M, et al: J Lab Clin Med 1997.

doi:10.1186/2197-425X-3-S1-A45

Cite this article as: Kleyman et al:: Differences in fat metabolism between predicted survivors and non-survivors of faecal peritonitis. Intensive Care Medicine Experimental 2015 3(Suppl 1):A45.

\section{Submit your manuscript to a SpringerOpen ${ }^{\circ}$ journal and benefit from:}

- Convenient online submission

- Rigorous peer review

- Immediate publication on acceptance

- Open access: articles freely available online

- High visibility within the field

- Retaining the copyright to your article

Submit your next manuscript at springeropen.com 